\title{
Identification of Causing Failure Factors of Service Providers in Winning The Project Tenders With Risk Management Approach
}

\author{
Eko Tavip Mariyanto \\ \{eko_tavip@yahoo.com\} \\ Universitas Pendidikan Muhammadiyah Sorongn, West Papua, Indonseia
}

\begin{abstract}
This is a survey research that has been conducted by describing opinions, behaviors, perceptions, actions or attitudes of respondents regarding with the failures to win the construction project bid, the determination of dominant risk events affecting the failure to win the tender and analysis of the appropriate response to the risks that arise within the bid construction project in the project tender process. The population used in this study were respondents who came from companies or contractors (bidders) both BUMN and private who are qualify. The respondents were directors, manager / procurement staff, manager / staff engineers, estimators, financial managers / staff, site managers or superintendents. The variable in question is a risk event that may occur and can affect the failure to win a contraction project tender conducted by a contractor.. The findings of this study are (1) Failure of the Auction Process is a research that discusses the auction process and factors that influence the failure to win this auction. It ended with finding the auction failure events, influential factors which can derail the winning of auction, the causing and analyzing of the responses. These findings are based on the method of risk management approach which is done by setting targets, assessing risks, responding, monitoring and reviewing and (2) auction management, based on interviews with auction management that has conducted by BUMN contractors in which there are actors who become research respondents. KUP has managed the auction and is running well. It can be seen from the results of the questionnaire stage I, which is based on the experience of respondents from 46 risky events / events that are asked about the frequency of occurrence and it is rarely reaching above $74 \%$. It proved that they have been able to manage the risk by reducing the frequency of occurrence of the failure causing and anticipating the impact of the occurrence. In terms of allowing the control procedures that is owned by the contractor, they have been able to reduce the failures in winning the auction.
\end{abstract}

Keywords: construction, project, analysis, auction

\section{Introduction}

One of the way to obtain a construction project is conducting and participating in bidding or project tenders. Bidding or tender is one of the activities that is carried out by construction service providers to get a construction project. Auction is a system of procurement materials or services. In 
the field of construction services, the auction is carried out by the assignor or the project owner by inviting several construction service companies or contractors to get one winner who is able to carry out and realize the project according to the requirements specified at a reasonable price and can be accounted in terms of time, quantity and quality.

In conducting the auction, there were more than one participant participating in this activity, resulting in a competition between each participant or contractor. The competition to win the bidding takes place at each contractor which will eventually be obtained by one contractor selected as the winner. On the other hand, there were many contractors who took part in the tender which were defeated, of course, this event was detrimental to the contractor because a lot of energy and the costs had been spent to be able to make the project offer. In addition, too much time has been devoted, although on the other hand there are points or values of goodness.

The high level of competition at this stage requires the contractors trying to do brilliant and professional ways to get the best results in winning the project offered. In its implementation, risks that arise both internally and externally within the company environment require the bidders to better manage their business. Considering the strengths and weaknesses of each participant in participating in the competition in this process will largely determine win or lose. In this case, the assignor will choose the most possible and best offer, which is based on certain conditions and specified conditions. Surely, this will be something that needs to be used as a basis for bidders in bidding, so that the auction activity chooses and determines its bid to be the best and win the tender.

The risk of not winning a winner's nomination is very likely occurred in the process. Only the best participants will be the winners in the competition. To be a winner in conducting a tender, a good management is needed to be considered as the best contractor by the project owner to carry out the offered project. The handling of tender implementation started from the decision whether they will be participate in the tender or not, the formation of a team to follow the process of tender activities will greatly affect the level of winning of the tender held by the project owner. Based on the description above, the objective in this research is to identify the factors that cause the failure of service providers in winning project tenders with a risk management approach.

\section{Methods}

\subsection{Types of Research}

This research survey has been conducted by describing the opinions, behaviors, perceptions, actions or attitudes of respondents regarding the events of failures to win the construction project bid, the determination of dominant risk events affecting the failure to win the tender and analysis of the appropriate response to the risks that arise within the bid construction project in the project tender process.

\subsection{Population and Sampling Criteria}

The population of this research were respondents who came from companies or contractors (bidders), both BUMN and private who have criteria /qualifications. The respondents can be directors, manager / procurement staff, manager / staff engineers, estimators, financial managers / staff, site managers or superintendents at PT. WK, PT. HK, PT. PDKA and PT. COUP. 


\subsection{Research Process / Stages}

Conducting literature studies from various libraries such as books, research journals, theses. They are used to find out the research variables namely factors that influence the win-lose events of construction project tenders that will be used as a basis for research. Conducting interviews and collecting questionnaires are used to obtain data research and obtain research variables and analyze data from the questionnaire with risk management in order to get the results which is obtained in the form of variables / risks and more concern in conducting project tenders by the contractor.

\subsection{Research variable}

Based on the results of the literature review from various literature, the variable in this research is a risk event that may occur and can affect the failure to win a contraction project tender conducted by the contractor.

\subsection{Research time}

This research has been conducted for 5 months at the Department of Public Works (PU) of Directorate General of Highways, BUMN and Private Construction Service Providers.

\subsection{Research Instruments}

In conducting this research, the instruments used in finding data are questionnaires and interviews with experts in the tender sector who are experienced in handling project tenders in several goods / service providers (contractors). In processing the survey data using the program risk management process approach used is Microsoft Office 2007.

\subsection{Data Collection and Analysis}

Collecting data and information on this research is more used research questionnaires. Questionnaire is a data collection technique that is done by giving a set of questions or written statements to the respondent to be answered, where in this study the respondent is a contractor. In the research questionnaire, the respondent answered the relative level of the likelihood of the frequency of occurrence of the variable and the level of impact that is caused by carrying out a checklist on the available columns. The questionnaire is intended to determine risk and risk level. Furthermore, the data collected in this study is qualitative data that is quantified in the form of respondents' opinions related to events that can frustrate project tenders. By anticipating the causes of tender failures using risk management, it is possible to win the tender or obtain a contract.

Table 1. Risk assessment scale

\begin{tabular}{llc}
\hline \multicolumn{1}{c}{ Degree of Risk } & \multicolumn{1}{c}{ Definition(function of) } & $\begin{array}{c}\text { Assessment } \\
\text { scale }\end{array}$ \\
\hline No risk (improbable lowest probability situation) & Lowest probability, Lowest severity & 0 \\
\hline Low risk & Probability, Lowest severity & 25 \\
\hline Moderate risk & $\begin{array}{l}\text { Moderate severity, Moderate probability, } \\
\text { Moderate, high probability }\end{array}$ & 50 \\
\hline High risk Prohibitive risk & High severity, High probability & $75-100$ \\
\hline
\end{tabular}

(Source : Makaran Hatta, 2000) 


\section{Result}

\subsection{General description of the respondent}

This research is divided into two stages: the first stage is looking and determining events that are risk to frustrate the auction and the level of risk of events and the second stage is looking for causes and determining how they affect the events that can be frustrate the auction. Based on the results of the validation and reliability of the questionnaire data, there were 15 respondents who passed the stage I, where the results of the data analysis will be used for follow-up in filling the questionnaire in stage II. In filling questionnaire at the stage II, there were only 9 respondents who was stated valid. This condition is more due to incomplete questionnaire data filling and the lack of information provided by respondents.

Based on the results of the stage I questionnaire with 46 points, it was found that the determinant variable which had a level of risk that became the main priority of the research was extreme and high risk levels (priority risk response), which then conducted an activity to find the causes of the event by interviews (previously) with several experts who then followed up by giving questionnaire instruments to respondents. Based on the results of literature studies and interviews, it is obtained the results that will be used as a stage II questionnaire variable as many as 27 points.

\subsection{Risky Events Thwart Tender}

\subsubsection{Events that frustrated tenders with a percentage of $100 \%$.}

Events, according to the whole respondent with a percentage of $100 \%$ contained in point A (not meeting the requirements / disqualification) that can frustrate the tender such as: documents incomplete requirements, lacking sub-contractor support, bid price is far from the owner estimate range.

According to all respondents, events that have a percentage of 100\% that can frustrate tenders at point B relating to not being proposed as the best candidate winners / nominees (did not get an invitation for clarification), that is bid price less competitive with other bidders. If there are 2 (two) or more bids with the same HEA or final evaluation price, then the bidder with the largest TKDN is the winner, the implementation schedule, and the budget plan are incomplete.

Whereas at the point $\mathrm{C}$, (clarification and negotiation cannot be accounted for) with a percentage of events $100 \%$ that could frustrate the tender such as unreliable negotiation skills, the clarification team lacks understanding of the proposed bidding documents, weak negotiation decision maker ability, absence clarification and negotiation and late present at the time of clarification and negotiation. In the point $\mathrm{D}$, it is related with the documents which are not proposed or designated as the winner of the tender, all events that have a percentage of $100 \%$ can derail the tender if they are unable to compete with other participants (having a lower value than others). There are submissions that are not approved and the tender team's lobbying and clarification capabilities are lacking / unconvincing. 


\subsubsection{Events which frustrate tenders with the percentage of $75 \%$}

Some factors that according to respondents are events that can frustrate tenders, such as late submitting bid documents, wrong envelope, incorrectly entering the contents of documents in the envelope, inappropriate volume, lack of ownership of the equipment, schedule of incomplete, incomplete bid bond plan, incorrect installation (company stamp / seal not initialed), excessive work scope and absence of company / initial seal on each requirement. Whereas the events that failed the tender with a percentage of $75 \%$ at point B namely construction method is not suitable (did not explain completion), the project cash flow did not meet owner / disapproved standards, safety management was incomplete, quality management was incomplete or it does not show quality product results, arithmetic errors, equipment procurement schedules, manpower and material defects, minimal team personnel qualifications, incomplete organizational structure, unclear / incomplete job scope, bid documents cannot be read / understood or cannot be evaluated, financial ability is less supportive, the weakness company ability in completing projects, the amount of work load (company work load) when conducting tenders and project work plans, lack of supplier support and lack of support and bank references (capital).

Furthermore, events which have a percentage of $75 \%$ can derail tenders at point $\mathrm{C}$, such as there is a lot of arithmetic, there is an analysis of incorrect technical specifications and there are some changes to the list of quantities and prices. In addition to the variables that have been listed in the questionnaire, there are also additional variables which according to respondents are events that can frustrate the tender namely stamp duty which is not given a date and the ability of the marketing team in lobbying is lacking.

\subsection{Risk Events That Affect Tender Failures}

To find out the level of risk of events that have been reduced in the previous data analysis, an approach with the frequency of occurring likelihood and the impact of the event is conducted with statistics and matrix of risk level can be showed as the following table:

Table 2. Risk Event

\begin{tabular}{|l|c|c|c|c|}
\hline \multirow{2}{*}{\multicolumn{1}{|c|}{ Likelihood }} & \multicolumn{4}{c|}{ Consequences } \\
\cline { 2 - 5 } & Minor & Moderate & Mayor & Malapetaka \\
\hline Very often & High & High & Extreme & Extreme \\
\hline Often & Moderate & Moderate & High & Extreme \\
\hline Sometimes & Low & Moderate & Moderate & Extreme \\
\hline Rarely & Low & Low & Low & Moderate \\
\hline
\end{tabular}

Based on the results of the analysis of the stage I questionnaire by reducing the 3 events that have been reduced from 46 events that frustrated the tender, the results obtained using frequency mode statistics that have been filled out by respondent risk levels as follows:

1. Extreme risk level: 0 occurrences (variable)

2. High risk level: 0 occurrences (variable)

3. Moderate risk level: 17 events (variable)

4. Low risk level: 26 events (variable) 
In connection with events that can frustrate a tender, the author will explain in three priority events that are very risky in thwarting a tender activity, they are:

1. Bid prices cannot compete with other bidders.

2. The technical proposal cannot compete with other participants (has a lower value weight).

3. The offer price is far above the owner estimate or capital owner range.

\subsection{Researcher Findings}

The research that discusses the auction process and the factors that influence the failure to win this auction will ultimately find the results in the form of auction failure events, influential factors can thwart the winning of the auction and the causes and analyze the responses. These findings are based on the method of risk management approach by setting goals, assessing risks, responding, monitoring and reviewing.

\subsubsection{Failure of the Auction Process}

Based on the results of interviews and information from several experts who are experts in their fields, there are 4 possible auction failure events that are experienced by the contracting bidders. The four failure events are:

1. Not eligible.

This event occurs when there are a number of conditions that must be fulfilled by bidders that are incomplete / incorrect or there are technical issues that abort the bid and it caused the offer to be not accepted or disqualification of the bid document.

2. Not nominated as the best nominee / nominated (Unreceiving a clarification invitation). It means that although the conditions submitted by the project owner have been completed, there are a few minimal assessments that cause it to be unable to compete with other bidders so that the bidding documents are not submitted as participants who get the best nominations to be invited to participate in clarification.

3. Irresponsible Clarification.

When clarifying the documents offered there are a number of items or things that are incompatible between the submission and the proposed bidding document. So that, according to the project owner the document is flawed or cannot be justified.

4. Responsible clarification but not propose as a winner.

It happens when the clarification and negotiation team is not able to explain in detail the purpose of the bid document or there are another participants who have more clarification performance compared to, so that they are deemed not to win it.

\subsubsection{Auction Management}

Based on data and information from the research questionnaire obtained from BUMN and private contractors, the result is as follows:

1. The analysis of risk responses must be based on the causes of the occurrence of risk events. Based on the literature of several experts in controlling the selection of projects to be followed, the auction team control started from the selection of team members who will be responsible. The clarification negotiation team is very important to greatly determine the increase in auction performance of a company. In addition, to control during the survey both of the project site 
survey and project resource requirements will greatly assist the management of the auction in implementation process.

2. Management of auctions which has been conducted by BUMN contractors who is also as respondents of this research, namely at PT. WK (Persero) tbk, PT. HK (Persero) tbk, PT. PDKA and PT. KUP have managed the auction and it is running well. It can be seen from the results of the questionnaire stage I, which is based on the experience of respondents from 46 risky events that are asked about the frequency of occurrence is rarely reaching above $74 \%$. This is prove that they have been able to manage the risk by reducing the frequency of occurrence of the causing failure and anticipating the impact of the occurrence. In this case by allowing the control procedures which is owned by the contractor to be able to reduce the causes that have the risk of failure to win the auction.

3. By knowing the events that can cause the risk of failure to win as well as the priority cause, the risk response analysis will be more targeted and more efficient and effective in managing auction performance. Thus, we can make an auction performance control procedure.

\section{Conclusions}

Based on the results and discussion, the writer can draw the following conclusions:

1. The incidents of failures in winning construction project bids on tender projects experienced by contractors are (1) disqualification or bid documents not fulfilling the requirements, (2) bid documents are not proposed as the best potential nominees / winners or do not receive an invitation for clarification, (3) clarification and negotiation cannot be guaranteed answer and, and (4) the document is not proposed or appointed as the tender winner.

2. The dominant risk events which are affected the failure of service providers (contractors) in winning tenders are: (1) bid prices are not competitive with other bidders, (2) technical proposals are not competitive with other participants and (3) the offer price is far above the owner estimate or capital owner range.

3. The result analysis of the response to the risk variable in this case the cost of the offer are: (1) the cost or price offered or submitted by the contractor is close to or is within the range that the owner estimate is acceptable; (2) the contractor must conduct a site survey and that survey in the form of quality, quantity and price continuously as well as collecting data about the worker's wages (HR) that apply in the area of the project location or wages in general, and: (3) the estimator must be able to carry out quantification of all that is presented in the work drawings and specifications and must anticipate all construction activities that will occur. While the analysis result of the response of technical proposals are: (1) the method of project implementation (construction, quality, and safety), (2) the project implementation schedule (time schedule) and (3) the factor of closeness of the relationship with the project owner. The response that must be carried are (1) controlling on the implementation of technical proposal making because it greatly influences the quality of the proposal so that the proposed implementation method of the project met the substantive requirements, specified in the tender document and believed to describe the mastery of completion of the project or work; (2) searching for information and data, developing 
various possible alternatives, conducting analysis and evaluation of various alternatives, selecting alternatives, implementing and providing input, and; (3) maintaining a good working relationship with the owner.

\section{References}

[1] Asiyanto, Ir. IPM. Construction Project Cost Management, ed: 3. Jakarta : PT. Pradnya Paramita. 2010.

[2] Batara. Analisa Persaingandalam Proses Tender Proyek Konstruksi dengan Simulasi Monte Carlo, (Depok: Departemen Teknik Sipil FTUI. 2009).

[3] Buree T, Barkley. "Project Risk Management". United State of America: McGraw-Hill. 2007.

[4] Burchet. Jhon E and Tumala. V.M.Rao, "The Application of Risk Management Processin Capital Investment Decision for EHV transmisión line project" Construction Management and Economics. Hong Kong. Edition.3., 2010.

[5] Crowley. Larry G. "Robust Statistical Estimators for Use within Competitive Bid Data". Construction Engineering and Management.2005

[6] Daryanto, Tri, Peran Kualitas Pengendalian Penyusunan Dokumen Penawaran Terhadap Perolehan Peringkat Pada Tender Proyek Konstruksi di PT Waskita Karya. (Depok: Departemen Teknik Sipil FTUI. 1998).

[7] Derek S Drew, W. K. FUI dan H. P. LO. "The Effect of Experience on Contractors Competitiveness in Recurrent Bidding”. Construction Management and Economics.. 2008.

[8] Febriano, Reza. "Penentuan bobot penilaian kriteria pada evaluasi penawaran pekerjaan jasa pemborongan di PT. JASA MARGA (persero) dengan menggunakan analytical hierarchy process". Depok: Departemen Teknik Sipil FTUI. 2008/2009.

[9] How Tenders Or Bids Are Awarded" http :/ / w w w.ca p ega teway.g ov.za / en g /tenders/ op en/ diakses04/05/2012 10: 21 am

[10] How to complete a tender or bid. http://www.capegateway.gov.za/eng/tenders/open diakses 06/05/2012, 4:34 pm.

[11] Peraturan Presiden Republik Indonesia Nomor 54 Tahun 2010 Tentang "Pedoman Pelaksanaan Pengadaan Barang Jasa Instansi Pemerintah".

[12] Keputusan Presiden Republik Indonesia Nomor 18 Tahun 2000 Tentang "Pedoman Pelaksanaan Pengadaan Barang Jasa Instansi Pemerintah”.

[13] Keputusan Presiden Republik Indonesia Nomor 80 Tahun 2003 Tentang "Pedoman Pelaksanaan Pengadaan Barang Jasa Pemerintah”. 